\title{
Recent advances in the electrochemical oxidation water treatment: Spotlight on byproduct control
}

\author{
Yang Yang (ه) \\ Department of Civil and Environmental Engineering, Clarkson University, Potsdam, NY 13699, USA
}

\section{H I G H L I G H T S}

- Byproduct formation mechanisms during electrochemical oxidation water treatment.

- Control byproduct formation by quenchers.

- Process optimization to suppress byproduct formation.

\section{A R T I C L E I N F O}

\section{Article history:}

Received 16 March 2020

Revised 3 May 2020

Accepted 19 May 2020

Available online 30 June 2020

Keywords:

Electrochemical water treatment

Byproducts

Perchlorate

\section{GRAPHIC A B S T R C T}
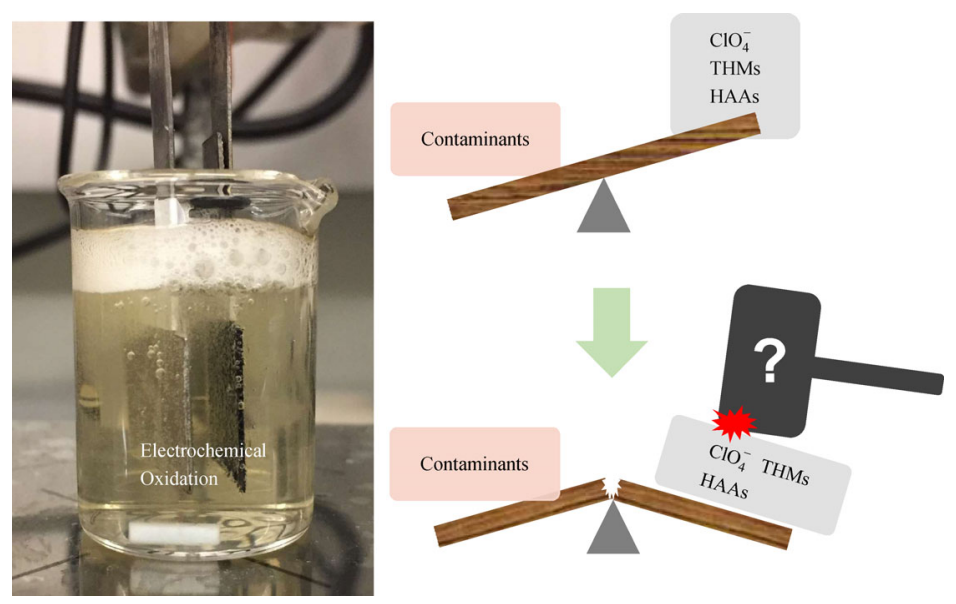

\section{A B S T R A C T}

Electrochemical oxidation (EO) is a promising technique for decentralized wastewater treatment, owing to its modular design, high efficiency, and ease of automation and transportation. The catalytic destruction of recalcitrant, non-biodegradable pollutants (per- and poly-fluoroalkyl substances (PFAS), pharmaceuticals, and personal care products (PPCPs), pesticides, etc.) is an appropriate niche for EO. EO can be more effective than homogeneous advanced oxidation processes for the degradation of recalcitrant chemicals inert to radical-mediated oxidation, because the potential of the anode can be made much higher than that of hydroxyl radicals $\left(\mathrm{E}_{\mathrm{OH}}=2.7 \mathrm{~V}\right.$ vs. NHE), forcing the direct transfer of electrons from pollutants to electrodes. Unfortunately, at such high anodic potential, chloride ions, which are ubiquitous in natural water systems, will be readily oxidized to chlorine and perchlorate. Perchlorate is a to-be-regulated byproduct, and chlorine can react with matrix organics to produce organic halogen compounds. In the past ten years, novel electrode materials and processes have been developed. However, spotlights were rarely focused on the control of byproduct formation during EO processes in a real-world context. When we use EO techniques to eliminate target contaminants with concentrations at $\mu \mathrm{g} / \mathrm{L}$-levels, byproducts at $\mathrm{mg} / \mathrm{L}$-levels might be produced. Is it a good trade-off? Is it possible to inhibit byproduct formation without compromising the performance of EO? In this minireview, we will summarize the recent advances and provide perspectives to address the above questions.

(C) The Author(s) 2020. This article is published with open access at link.springer.com and journal.hep. com.cn 2020

\section{$\triangle$ Corresponding author}

E-mail: yanyang@clarkson.edu

Special Issue-Accounts of Aquatic Chemistry and Technology Research (Responsible Editors: Jinyong Liu, Haoran Wei \& Yin Wang)

\section{Introduction}

Electrochemical oxidation (EO) is a promising technology for the fast treatment of recalcitrant chemicals. It features a compact and modular design. A typical EO reactor only 
requires DC power supply and electrode array, and it is usually operated in open air at room temperature. The treatment capacity of EO processes is scalable, depending on the numbers and areas of electrode arrays used. EO exhibited excellent performance on the destruction of nonbiodegradable pollutants (PFAS, PPCPs, pesticides, etc.) (Carter and Farrell, 2008; Zhuo et al., 2012; Jasper et al., 2016). For example, recent advances show that one-log removal of typical PFAS (perfluorooctanesulfonic acid (PFOS) and perfluorooctanoic acid (PFOA)) and PPCPs (carbamazepine, metoprolol, and ciprofloxacin) can be achieved at energy consumptions less than $10 \mathrm{kWh} / \mathrm{m}^{3}$ (Jasper et al., 2016; Le et al., 2019; Yang et al., 2019a).

By tuning the anodic potential, various oxidants $\left(\mathrm{OCl}^{-}\right.$, $\mathrm{O}_{3}, \mathrm{Cl} \cdot, \cdot \mathrm{OH}$, etc.) can be produced at the anodes (Fig. 1). EO is more efficient than the homogeneous advanced oxidation processes (AOPs) on the degradation of pollutants that barely react with radicals, because the potential of anodes can be made much higher than that of hydroxyl radicals $\left(E_{\mathrm{OH}}=2.7 \mathrm{~V}\right.$ vs. NHE), forcing the direct transfer of electrons from target compounds to electrodes. For instance, perfluorooctanoate $\left(\mathrm{C}_{7} \mathrm{~F}_{15} \mathrm{COO}^{-}\right)$ is resistant to $\cdot \mathrm{OH}$ oxidation. However, it can be readily destroyed by EO via direct electron transfer (DET) oxidation (Niu et al., 2013).

The generation of oxidants requires high anodic potential. Unfortunately, at such high anodic potential, chloride ions, which are ubiquitous in natural water systems, will be readily oxidized to free chlorine $(\mathrm{HClO} /$ $\mathrm{OCl}^{-} ; \mathrm{pK}_{\mathrm{a}}$ 7.5) and then further oxidized to perchlorate $\left(\mathrm{ClO}_{4}^{-}\right)$. Perchlorate is an endocrine disruptor posing an adverse impact on thyroid gland function (Urbansky and Schock, 1999). In 2019, the US Environmental Protection
Agency (EPA) proposed a maximum contaminant level at $56 \mu \mathrm{g} / \mathrm{L}$. Some US states have already regulated $\mathrm{ClO}_{4}{ }^{-}$in drinking water at lower levels $(2 \mu \mathrm{g} / \mathrm{L}$ for Massachusetts and $6 \mu \mathrm{g} / \mathrm{L}$ for California). Current experimental results indicate that, once it is formed, the elimination of $\mathrm{ClO}_{4}^{-}$is very challenging (Schaefer et al., 2007; Liu et al., 2016).

In most of the cases, free chlorine generated in EO treatment facilitates the removal of organic and enhances the inactivation of pathogens. However, it also reacts with organics to form disinfection byproducts (DBPs). USEPA regulated five haloacetic acids (HAAs), including monochloroacetic acid (MCAA), dichloroacetic acid (DCAA), trichloroacetic acid (TCAA), monobromoacetic acid (MBAA), and dibromoacetic acid (DBAA), with a combined concentration of $<60 \mu \mathrm{g} / \mathrm{L}$ in drinking water, and four trihalomethanes (THMs: chloroform, bromodichloromethane, dibromochloromethane, and bromoform) with a maximum combined concentration of $80 \mu \mathrm{g} / \mathrm{L}$ (USEPA, 2010). Nowadays, more than 600 DBPs were identified (Richardson et al., 2007; Li and Mitch, 2018), and some unregulated nitrogenous DBPs (nitrosamine, haloacetonitriles, etc.) have orders of magnitude higher toxic potencies than THMs and HAAs (Wagner and Plewa, 2017).

In the area of electrochemical disinfection, balancing the acute risk caused by pathogens against the chronic carcinogenic risk associated with DBPs is an endless debate. As for the treatment of recalcitrant chemical contaminants and pathogen inactivation, it is clear that DBPs $(\mu \mathrm{g} / \mathrm{L}-$ level) and perchlorate $(\mathrm{mg} / \mathrm{L}$-level) are produced during the removal of $\mu \mathrm{g} / \mathrm{L}$-level target compounds (or cells/L-level pathogens) in chloride bearing surface water and waste stream (Anglada et al., 2009,

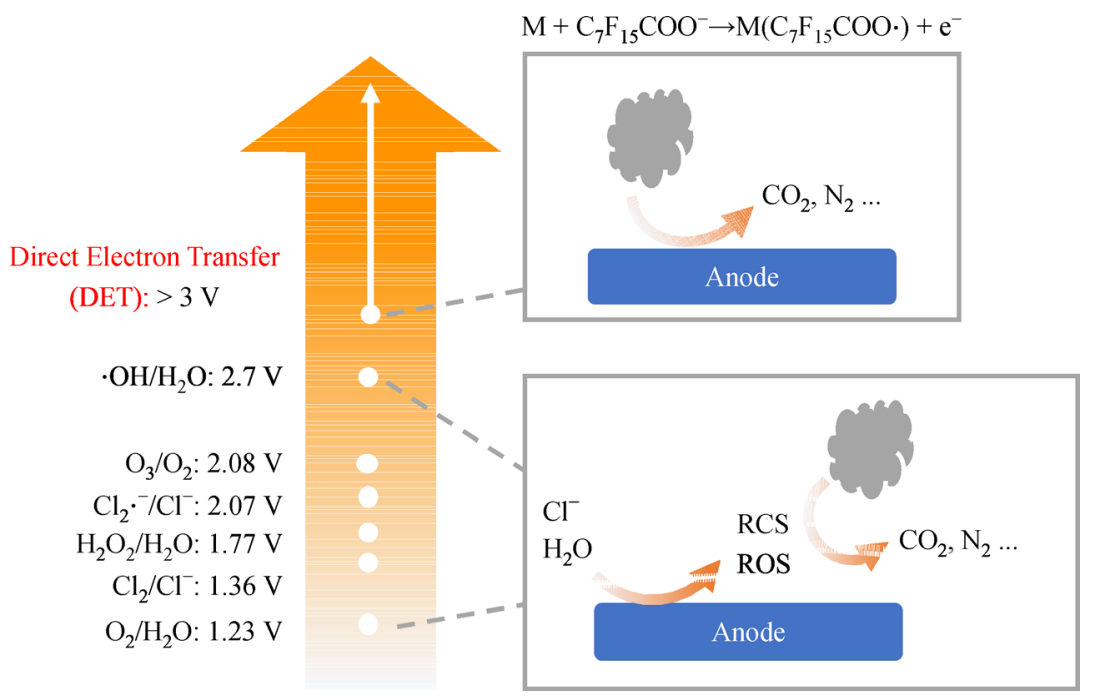

Fig. 1 Oxidation power of oxidants and direct electron transfer reactions characterized in the scale of redox potentials. The bottom frame shows the mechanism of indirect oxidation, in which target compounds react with reactive chlorine species (RCS) and reactive oxygen species (ROS) generated electrochemically. The top frame demonstrates the oxidation reactions based on the direct electron transfer mechanism. 
2010; Bagastyo et al., 2013; Schaefer et al., 2015; Yang et al., 2019a). These facts keep us wondering whether adopting EO treatment is a good trade-off.

Despite that breakthroughs were made on the development of novel electrode materials, it is equally important to work on the control of byproducts. This review primarily focuses on the control of THMs, HAAs, and $\mathrm{ClO}_{4}{ }^{-}$as they are facing regulatory pressure. It is also important to note that THMs and HAAs could serve as indicators of exposure to the complex mixture of DBPs. The concentrations of THMs and HAAs are usually proportional to the total organic halogen concentrations in treated effluents (Pourmoghaddas and Stevens, 1995). Although this correlation has not been proved for the EO systems, we speculate that through the control of THMs, HAAs, and $\mathrm{ClO}_{4}^{-}$, the overall reduction of other unknown halogen byproducts can be achieved.

It is also important to address that health concerns of DBPs and $\mathrm{ClO}_{4}^{-}$were initially raised by the drinking water treatment sector. EO is less likely to be applied to treat drinking water with low conductivity. In wastewater treatment, the control of byproducts seems to be unnecessary as the effluents are not required to be treated to a drinkable degree. However, the author believes it is still important to investigate the byproduct suppression strategies in the EO treatment of wastewater, and in some case, drinking water due to the following reasons:

1) Some studies demonstrated that EO could be used to treat the emerging contaminants and inactivate pathogens in drinking water and surface water at acceptable energy consumption levels (less than $10 \mathrm{kWh} / \mathrm{m}^{3}$ ) (MartínezHuitle and Brillas, 2008; Schaefer et al., 2015; Yang et al., 2019a).

2) Effluents from the EO wastewater treatment units containing (DBPs) will eventually be discharged to the

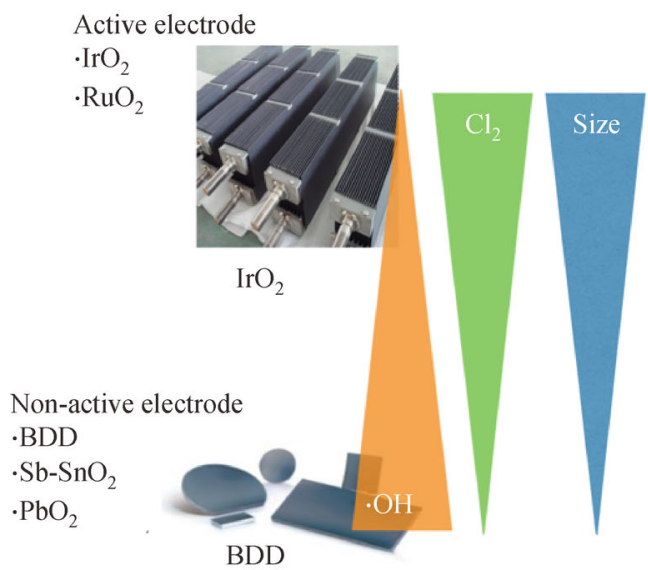

(a) surface water, which could potentially be utilized downstream as a potable water supply.

3) The author has received review comments from almost every article and proposal, requiring the evaluation of DBPs formation in the EO processes, even though the technique was proposed for wastewater treatment. These comments were raised due to the high expectations from broad scientific and industrial communities on the emerging EO technology. "The control of byproducts in the EO reactions in all matrices." The author believes this is a question of when, not if.

\section{Byproduct formation during EO treatment}

\subsection{Electrode materials}

The performance of $\mathrm{EO}$ and the byproduct generation rates are largely dependent on the properties of electrodes. As shown in Fig. 2(a), depending on the activity of water oxidation, electrodes can be categorized as active and nonactive electrodes (Chaplin, 2014; Martínez-Huitle et al. 2015; Chaplin, 2019). The property of electrodes can be identified by cyclic voltammetry (CV) analysis (Fig. 2(b)). In these tests, electrodes are immersed into the inert electrolyte (e.g., $\mathrm{Na}_{2} \mathrm{SO}_{4}$ or $\mathrm{NaClO}_{4}$ ). The anodic potential is increased at a fixed rate, and the response of current is recorded. Assume that all the electrons withdrawn from the anode are only contributed by water oxidation $\left(2 \mathrm{H}_{2} \mathrm{O} \rightarrow\right.$ $\mathrm{O}_{2}+4 \mathrm{H}^{+}+4 \mathrm{e}^{-}$), the larger current recorded implies faster reaction rates. In the CV analysis of the active electrodes, the sharp increase of current usually occurs at $1.5 \mathrm{~V}_{\mathrm{RHE}}$. These onset potentials are slightly higher than the theoretical potential for water oxidation (1.23 $\left.\mathrm{V}_{\text {RHE }}\right)$. Therefore, it is concluded that active electrodes have low

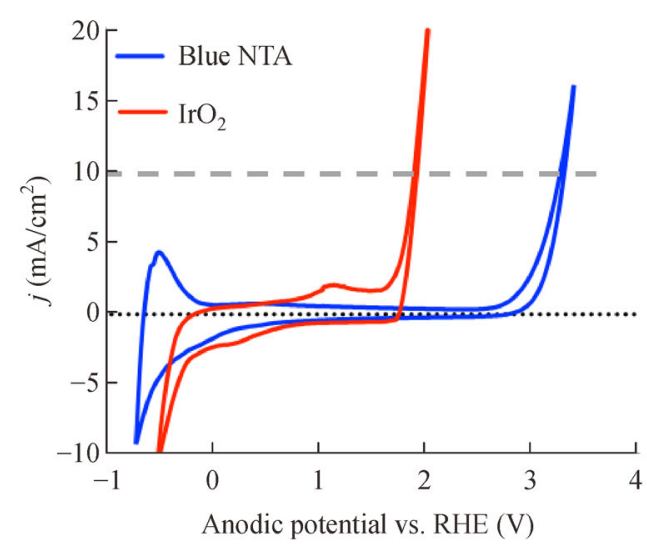

(b)

Fig. 2 (a) Classification and properties of active and non-active anodes. (b) Cyclic voltammetry analysis of electrodes in $30 \mathrm{mmol} / \mathrm{L}$ $\mathrm{N}_{2} \mathrm{SO}_{4}$ electrolyte. $\mathrm{IrO}_{2}$ and blue $\mathrm{TiO}_{2-x}$ nanotube array (NTA) represent active and non-active electrodes, respectively. Data was collected from reference (Yang and Hoffmann, 2016). 
overpotentials for oxygen evolution. Typical Active electrodes include $\mathrm{RuO}_{2}$ and $\mathrm{IrO}_{2}$. As for nonactive electrodes, such as $\mathrm{PbO}_{2}, \mathrm{Sb}-\mathrm{SnO}_{2}$, boron-doped diamond (BDD), and sub-stoichiometric $\mathrm{TiO}_{2-x}$ electrodes, their onset potentials usually are higher than $2 \mathrm{~V}_{\mathrm{RHE}}$.

The different activities toward oxygen evolution stems from the surface chemistry of electrode materials. Mechanisms are well explained in previous studies (Trasatti, 1984; P. Chaplin, 2014). During electrolysis, - $\mathrm{OH}$ is produced from water as a surficial intermediate. The $\cdot \mathrm{OH}$ strongly binds with the active electrode $\left(\mathrm{M}^{\mathrm{n}} \mathrm{O}\right)$, and is rapidly incorporated into its lattice structure to form higher oxide $\left(\mathrm{M}^{\mathrm{n}+1} \mathrm{O}\right)$, then the reaction proceeds to produce $\mathrm{O}_{2}$. As for non-active electrode, $\cdot \mathrm{OH}$ loosely binds with the electrode surface. The oxygen production is hence disfavored.

Assume that both active and non-active electrodes are operated at a constant current density of $10 \mathrm{~mA} / \mathrm{cm}^{2}$ (Fig. 2(b)), the active electrode at $2 \mathrm{~V}_{\mathrm{RHE}}$ can only produce chlorine $\left(\mathrm{Cl}_{2} / \mathrm{Cl}^{-} 1.36 \mathrm{~V}_{\mathrm{RHE}}\right)$. The non-active electrode has a potential of $3.2 \mathrm{~V}_{\mathrm{RHE}}$, which is high enough to satisfy the thermodynamic criteria for the production of multiple oxidants such as $\cdot \mathrm{OH}, \mathrm{O}_{3}$, and $\mathrm{H}_{2} \mathrm{O}_{2}$ (Fig. 1).

Since oxygen evolution shares similar mechanisms with chlorine evolution (Krishtalik, 1981), active electrodes have high efficiency for chlorine production. The free chorine produced can efficiently inactivate pathogens and remove ammonium via breakpoint chlorination. As for nonactive electrodes, they demonstrate superior performance on the degradation of recalcitrant organic compounds that are inert to free chlorine but reactive toward radicals.

Electrolysis using active electrodes tends to produce DBPs due to the buildup of free chlorine to react with matrix organics in bulk solution (vide infra). In contrast, nonactive electrodes are oxidative enough to mineralize organic contaminants and destroy the as-formed DBPs (Jasper et al., 2017), but their strong oxidation capability leads to the rapid oxidation of free chlorine to $\mathrm{ClO}_{4}{ }^{-}$.

\subsection{Formation of perchlorate}

In the EO reaction, $\mathrm{Cl}^{-}$is oxidized to free chlorine, $\mathrm{ClO}_{3}{ }^{-}$, then to $\mathrm{ClO}_{4}^{-}$. The electrochemical chlorine evolution follows the Volmer-Heyrovsky mechanism (Trasatti, 1987; Consonni et al., 1987): $\mathrm{Cl}^{-}$is first adsorbed onto the anode surface to discharge one electron (rxn. 1).

$$
\begin{gathered}
\mathrm{MnO}_{x}+\mathrm{Cl}^{-} \rightarrow \mathrm{MO}_{x}(\mathrm{Cl} \cdot)+\mathrm{e}^{-} \\
\mathrm{MO}_{x}(\mathrm{Cl} \cdot)+\mathrm{Cl}^{-} \rightarrow \mathrm{MO}_{x}+\mathrm{Cl}_{2}+\mathrm{e}^{-} \\
2 \mathrm{MO}_{x}(\mathrm{Cl} \cdot) \rightarrow 2 \mathrm{MO}_{x}+\mathrm{Cl}_{2}
\end{gathered}
$$

The adsorbed chlorine radical then combines with $\mathrm{Cl}^{-}$in the bulk solution or with neighboring surficial $\mathrm{Cl}$ - to produce $\mathrm{Cl}_{2}$ (rxn. 2 and 3), which subsequently hydrolyze to $\mathrm{HOCl}$ or $\mathrm{OCl}^{-}$depending on $\mathrm{pH}$.

With longer electrolysis duration, free chlorine will undergo a combination of DET oxidation (rxn. 4, 6, and 8) and $\cdot \mathrm{OH}$ mediated oxidation to form $\mathrm{ClO}_{3}{ }^{-}$and $\mathrm{ClO}_{4}{ }^{-}$ (Bergmann et al., 2014; Hubler et al., 2014).

$$
\begin{gathered}
\mathrm{OCl}^{-} \rightarrow \mathrm{OCl} \cdot+\mathrm{e}^{-} \\
\mathrm{OCl} \cdot+\cdot \mathrm{OH} \rightarrow \mathrm{ClO}_{2}{ }^{-}+\mathrm{H}^{+} \\
\mathrm{ClO}_{2}{ }^{-} \rightarrow \mathrm{ClO}_{2} \cdot+\mathrm{e}^{-} \\
\mathrm{ClO}_{2} \cdot+\cdot \mathrm{OH} \rightarrow \mathrm{ClO}_{3}{ }^{-}+\mathrm{H}^{+} \\
\mathrm{ClO}_{3}{ }^{-} \rightarrow \mathrm{ClO}_{3} \cdot+\mathrm{e}^{-} \\
\mathrm{ClO}_{3} \cdot+\cdot \mathrm{OH} \rightarrow \mathrm{ClO}_{4}{ }^{-}+\mathrm{H}^{+}
\end{gathered}
$$

The homogeneous reaction of chlorite $\left(\mathrm{ClO}_{2}^{-}\right)$and free chlorine could produce $\mathrm{ClO}_{3}^{-}$(Gordon and Tachiyashiki, 1991). However, the contribution of this step to $\mathrm{ClO}_{4}{ }^{-}$ formation in EO treatment might be minimal, as the chlorine balance analyses showed that the concentrations of $\mathrm{ClO}_{2}{ }^{-}$in the bulk electrolyte are negligible (Yang et al., 2016, 2019a; Mostafa et al., 2018). Our studies on the EO treatment of latrine wastewater (a mixture of feces and urine) showed that at moderate current density $(10 \mathrm{~mA} /$ $\mathrm{cm}^{2}$ ), $\mathrm{IrO}_{2}$ electrode was inert to, while BDD electrode was quite reactive to $\mathrm{ClO}_{4}^{-}$generation (Yang et al., 2016; Yang and Hoffmann, 2016; Jasper et al., 2017). Interestingly, a study focusing on EO treatment of urine reported that at a higher current density $\left(20 \mathrm{~mA} / \mathrm{cm}^{2}\right)$, the $\mathrm{IrO}_{2}$ electrode was able to produce $\mathrm{ClO}_{4}^{-}$. When active electrode $\mathrm{Pt} / \mathrm{Ti}$ was operated at $270 \mathrm{~mA} / \mathrm{cm}^{2}$, the production of $\mathrm{ClO}_{4}{ }^{-}$was observed as well (Jung et al., 2010). These recent studies break the stereotype that active anode cannot produce $\mathrm{ClO}_{4}^{-}$. In fact, both active and nonactive electrodes can produce $\mathrm{ClO}_{4}^{-}$when the thermodynamic criteria (e.g., anodic potential and current density) are met. The kinetics of the multi-step oxidation of chlorine oxyanions ( $r x n$ 4-9) at the electrode/electrolyte interface determines how fast the $\mathrm{ClO}_{4}{ }^{-}$can be produced.

\subsection{Formation of DBPs}

The DBP formation mechanisms in EO treatment were rarely investigated specifically. Therefore, mechanisms discovered in disinfection are revealing. THMs and HAAs result from reactions between free chlorine and natural organic matters (NOMs) in the drinking water disinfection process (Bond et al., 2012). NOMs could be considered as surrogates for most of the organic contaminants of concern, as NOMs have multiple functional groups: carboxylic acid, enolic hydrogen, phenolic hydrogen, 
quinine, alcoholic hydroxyl, ether, ketone, aldehyde, ester, lactone, amide and amine (Thurman, 2012). Free chlorine reacts with NOMs through oxidation, addition, and electrophilic substitution. In general, aromatic precursors have THM and HAA formation potentials (2$1892 \mu \mathrm{g} / \mathrm{mg} \mathrm{C}$ ) two to three orders of magnitude higher than aliphatic precursors (Bond et al., 2012). High $\mathrm{pH}$ favors the formation of DBPs by promoting the hydrolysis of halogenated leaving group (Fig. 3). Long contact time and high chlorine/organic ratio promote the formation of THMs and HAAs (Sérodes et al., 2003; Sun et al., 2009).

Learning from the above, we know that both aliphatic and aromatic compounds, no matter they are target pollutants or matrix organics, can react with chlorine to produce DBPs. But the formation of DBPs is not that easy. It requires multiple steps (long contact time), appropriate $\mathrm{pH}$, and high chlorine dose. Therefore, it is possible to control DBPs by adjusting the operational parameters and reaction conditions of EO treatment (vide infra).

In homogeneous chlorination disinfection operation, free chlorine at high concentration is spiked in water initially. As for EO treatment, chlorine is gradually generated. DBP formation is usually insignificant at the early-stage of electrolysis because free chlorine will be instantly consumed by excessive organics and ammonium. Organics are not yet broken down to small molecule precursors with abundant halogen leaving groups. Sharp increase of DBPs was reported when the majority of organics was removed ( $>90 \%$ removal of COD) accompanied by the rapid increase of free chlorine concentration (Zöllig et al., 2015; Jasper et al., 2017). These results indicate that the DBP formation during electrolysis is still dominated by the homogeneous reactions in the bulk solution. Most of the studies reported that active electrodes tend to produce more DBPs than non-active electrodes because the former produces more free chlorine. However, a few conflicting results were reported. Bagastyo et al. (2012, 2013) studied the formation of THMs and HAAs during the electrolysis of $\mathrm{RO}$ concentrate using $\mathrm{IrO}_{2}$ and BDD electrodes. In this study, the BDD electrode produces more HAAs and THMs than $\mathrm{IrO}_{2}$. The authors speculated that BDD oxidized chloride to chlorine radicals $(\mathrm{Cl} \cdot)$ and dichloride radical anion $\left(\mathrm{Cl}_{2} \cdot{ }^{-}\right)$. The chlorine radicals might be able to react with organics to form DBPs.

\section{Control strategies}

\subsection{Fabricate anode materials}

Pralay et al. use perfluoro-decyl trichlorosilane to fabricate the surface of BDD with the goal of inhibiting DET steps (rxn. 5, 7, and 9) via steric hindrance and hydrophobic effects (Gayen and Chaplin, 2017). The fluorinated polymeric coating prevents the direct contact between $\mathrm{ClO}_{3}{ }^{-}$and $\mathrm{BDD}$ surface but allows $\cdot \mathrm{OH}$ to diffuse into the bulk electrolyte. Another study reported that covering the BDD surface with perfluorooctanoic acid (PFOA) could inhibit the formation of $\mathrm{ClO}_{4}{ }^{-}$(Jawando et al., 2015). This result implies that the $\mathrm{EO}$ process could produce less $\mathrm{ClO}_{4}$ during the treatment of per- and poly-fluorinated chemical waste at high concentrations. It is important to note that the above studies operated BDD at low current densities (ca. 1 $\mathrm{mA} / \mathrm{cm}^{2}$ ). At higher current densities, the stability of the surface coating will be a critical issue, as BDD electrodes can oxidize the poly-and perfluoroalkyl coatings. Our study found that significant formation of $\mathrm{ClO}_{4}^{-}$was still observed when BDD was operated at $10 \mathrm{~mA} / \mathrm{cm}^{2}$ to treat $10 \mathrm{mg} / \mathrm{L}$ PFOA in the presence of $3 \mathrm{mmol} / \mathrm{L} \mathrm{Cl}^{-}$(Yang et al., 2019a). Forming less $\mathrm{ClO}_{4}{ }^{-}$during treatment of high

(a)

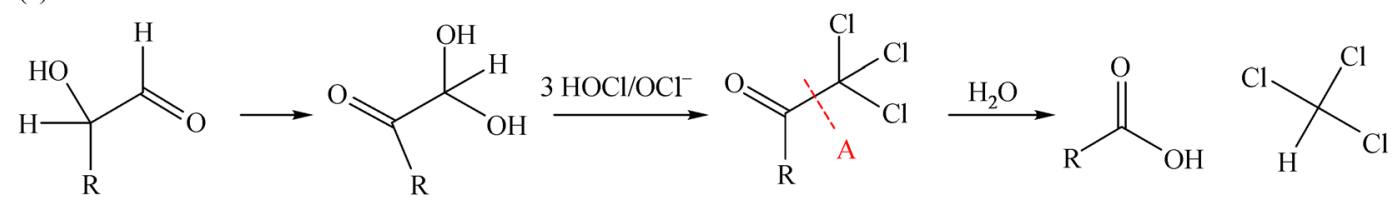

(b)

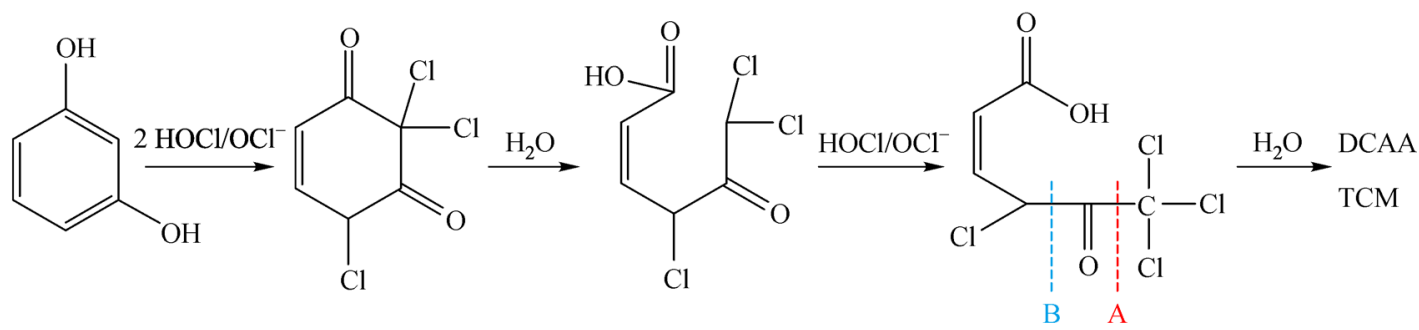

Fig. 3 Formation of trichloromethane and trichloroacetic acid in the chlorination of a) aliphatic carbohydrates and b) aromatic compounds (based on ref's (Rook, 1977; Boyce and Hornig, 1983; Navalon et al., 2008; Bond et al., 2012)). Cleavage at sites A and B leads to the formation of trichloromethane (TCM) and dichloroacetic acid (DCAA), respectively. 
PFAS concentration may be important in the PFAS remediation process. However, it cannot be applied as a general strategy to mitigate $\mathrm{ClO}_{4}{ }^{-}$formation.

Another option is to use alternative electrodes for BDD. Active electrodes such as $\mathrm{Pt} / \mathrm{Ti}, \mathrm{IrO}_{2} / \mathrm{Ti}$, and $\mathrm{RuO}_{2} / \mathrm{Ti}$ have lower $\mathrm{ClO}_{4}{ }^{-}$formation potentials, but they are also less efficient for organic oxidation. Recently, sub-stoichiometric $\mathrm{TiO}_{2-x}$ NTA and $\mathrm{Ti}_{4} \mathrm{O}_{7}$ phase anode were developed with comparable performance with BDD (Zaky and Chaplin, 2013; Zaky and Chaplin, 2014; Yang and Hoffmann, 2016; Yang et al., 2018). These $\mathrm{TiO}_{2-x}$ electrodes produced less $\mathrm{ClO}_{4}^{-}$than BDD (Yang and Hoffmann, 2016; Wang et al., 2020). Though the molecular-scale mechanism is still unclear, we suspected that $\cdot \mathrm{OH}$-mediated oxidation, rather than DET, is the major contaminant removal mechanism on $\mathrm{TiO}_{2-x}$ electrodes with abundant surficial titanol groups (Kesselman et al., 1997; Bejan et al., 2012), while BDD has higher reactivity for DET mediated oxidation, which favors the $\mathrm{ClO}_{4}{ }^{-}$ formation.

\subsection{Enhance cathodic dehalogenation}

Typical EO cells use stainless steel or Ti metal as cathodes, on which hydrogen evolution reaction (HER) occurs via proton reduction. It is viable to replace the HER cathodes with catalytic electrodes that can reductively remove perchlorate and DBPs. Perchlorate can be electrochemically reduced by $\mathrm{Rh}, \mathrm{Pt}, \mathrm{Sn}, \mathrm{Cu}$, and $\mathrm{Ni}$ (Horányi and Bakos, 1992; Wasberg and Horányi, 1995; Wang et al., 2007). Reactions can be described by the LangmuirHinshelwood model: $\mathrm{ClO}_{4}^{-}$is adsorbed on to cathode surface, transfer one oxygen atom to the cathode, and then react with neighboring reactive atomic hydrogen $(\cdot \mathrm{H})$, which is an intermediate of HER. Alloy could have a higher $\mathrm{ClO}_{4}^{-}$reduction activity. Ni-Pt and Co-Pt outperformed pure $\mathrm{Pt}$ due to the enhanced production of $\cdot \mathrm{H}$ (Rusanova et al., 2006; Mahmudov et al., 2008). However, long electrolysis duration $\left(t_{1 / 2}=4-5 \mathrm{~h}\right)$, acidic media, and elevated temperature $\left(>50{ }^{\circ} \mathrm{C}\right)$ are required for electrochemical $\mathrm{ClO}_{4}^{-}$reduction. The sluggish cathodic $\mathrm{ClO}_{4}{ }^{-}$ reduction kinetics is incomparable to the fast formation rate on the anode.

Cathode materials like $\mathrm{Fe}, \mathrm{Pd}-\mathrm{Fe}, \mathrm{Pd}, \mathrm{Cu}$, graphene, and graphite exhibit high activity for THM and HAA reduction (Li and Farrell, 2000; Radjenović et al., 2012; Mao et al., 2016; Mao et al., 2018). The electrochemical reductive removal of THMs and HAAs is faster than $\mathrm{ClO}_{4}{ }^{-}$reduction as THMs and HAAs are directly reduced by $\cdot H$, and no oxygen transfer step is involved. Complete removal HAAs could be achieved within an hour. The removal of THMs is even faster due to the volatilization effect.

To the best of our knowledge, there is no study showing that cathodic dehalogenation can completely eliminate the DBPs and perchlorate produced by anode to achieve the zero-DBP discharge. Aside from the low $\cdot \mathrm{H}$ production efficiency, the sluggish reduction kinetics could largely be assigned to the fact that DBPs and perchlorate are neutral or negatively charged at circumneutral $\mathrm{pH}$, making their adsorption on cathode difficult. Recently Chaplin et al. developed a carbon- $\mathrm{Ti}_{4} \mathrm{O}_{7}$ reactive electrochemical membrane (REM) cathode (Almassi et al., 2020). The REM was operated in a flow-through mode, in which water was forced to pass through the microporous cathode. The firstorder rate constant for dibromoacetic acid reduction is 9.16 $\mathrm{min}^{-1}$, which is 57 to 1110 times higher than those obtained in batch mode (Mao et al., 2016, 2018). Changing the operational mode from flow-by to flow-through dramatically reduces the thickness of the diffusional boundary layer from $\sim 100 \mu \mathrm{m}$ for plate-type electrodes to $\sim 1 \mu \mathrm{m}$ for REM electrodes (Chaplin, 2019), leading to a more efficient contact between target compounds and the electrode surface. Given the above, it is promising to develop tandem REM anode + REM cathode modules to remove contaminants and eliminate byproducts simultaneously.

\subsection{Quench byproduct precursors}

Introducing free chlorine quencher during electrolysis could suppress the formation of DBPs and $\mathrm{ClO}_{4}{ }^{-}$. Hydrogen peroxide $\left(\mathrm{H}_{2} \mathrm{O}_{2}\right)$ is an ideal quencher because it is effective, inexpensive, and widely used in site remediation projects. $\mathrm{H}_{2} \mathrm{O}_{2}$ readily reacts with free chlorine to form $\mathrm{Cl}^{-}$and $\mathrm{H}_{2} \mathrm{O}$ (Connick, 1947). Our recent study (Yang et al., 2019a) found that adding $50 \mathrm{mmol} / \mathrm{L}$ $\mathrm{H}_{2} \mathrm{O}_{2}$ can effectively inhibit $\mathrm{ClO}_{4}^{-}$formation in EO treatment of PFOS using BDD anode (Fig. 4). According to rxn. 4-9, $\mathrm{ClO}_{4}^{-}$formation could be suppressed by scavenging free chlorine and $\cdot \mathrm{OH}$. Through computational kinetic modeling, it is found that although $\mathrm{H}_{2} \mathrm{O}_{2}$ reacts with free chlorine more slowly than with $\cdot \mathrm{OH}\left(\sim 10^{4}\right.$ vs. $\sim 10^{7} \mathrm{M}^{-1} \mathrm{~s}^{-1}$ ), the former reaction contributes the most to $\mathrm{ClO}_{4}^{-}$inhibition.

$\mathrm{H}_{2} \mathrm{O}_{2}$ can be in situ generated by cathode via oxygen reduction reaction $\left(\mathrm{O}_{2}+2 \mathrm{H}^{+}+2 \mathrm{e}^{-} \rightarrow \mathrm{H}_{2} \mathrm{O}_{2}\right)$. For example, in the electro-Fenton process, $\mathrm{H}_{2} \mathrm{O}_{2}$ is generated at carbonaceous cathodes and then react with $\mathrm{Fe}^{2+}$ to produce $\cdot \mathrm{OH}$ as an oxidant (Brillas et al., 2009). Interestingly, in the electro-Fenton process, $\mathrm{ClO}_{3}{ }^{-}, \mathrm{ClO}_{4}{ }^{-}$ and THMs were not detected (Cotillas et al., 2015). Note that this study used low current densities (0.12$2.5 \mathrm{~mA} / \mathrm{cm}^{2}$ ). Thus, the intrinsic formation rates of DBPs and $\mathrm{ClO}_{4}^{-}$might be small. Electro-peroxone process is another EO technique that involves cathodic $\mathrm{H}_{2} \mathrm{O}_{2}$ production (Yuan et al., 2013). In this process, $\mathrm{O}_{3}$ and $\mathrm{O}_{2}$ are purged to the electrolyte simultaneously. Oxygen will be reduced to $\mathrm{H}_{2} \mathrm{O}_{2}$ and then react with $\mathrm{O}_{3}$ to produce radicals (rxn. 10).

$$
\mathrm{H}_{2} \mathrm{O}_{2}+\mathrm{O}_{3} \rightarrow \cdot \mathrm{OH}+\cdot \mathrm{O}_{2}{ }^{-}+\mathrm{H}^{+}+\mathrm{O}_{2}
$$




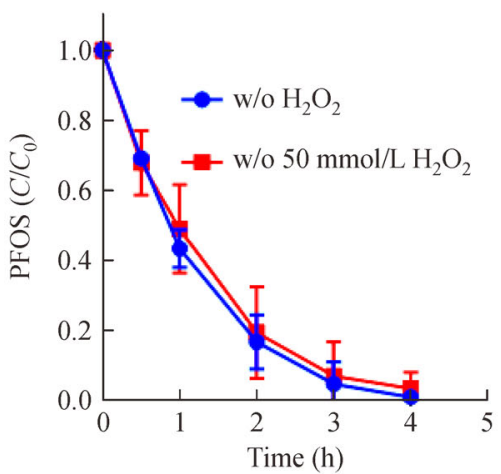

(a)

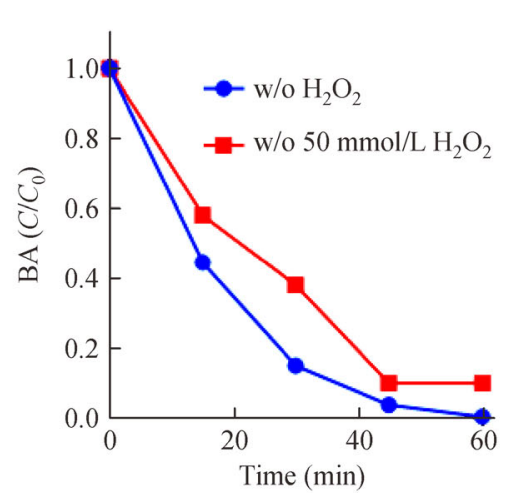

(b)

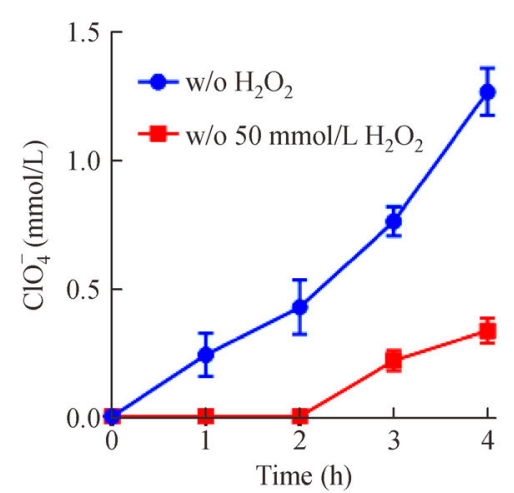

(c)

Fig. 4 Degradation of (a) PFOS (10 mg/L) and (b) benzoic acid (1 mmol/L), and (c) the formation of $\mathrm{ClO}_{4}{ }^{-}$during electrolysis in 15 $\mathrm{mmol} / \mathrm{L} \mathrm{Na}_{2} \mathrm{SO}_{4}+3 \mathrm{mmol} / \mathrm{L} \mathrm{NaCl}$ electrolytes in the presence or absence of $\mathrm{H}_{2} \mathrm{O}_{2}(50 \mathrm{mmol} / \mathrm{L})$. BDD anode was coupled with stainless steel cathode and operated at $10 \mathrm{~mA} / \mathrm{cm}^{2}$. Data was collected from reference (Yang et al., 2019a).

The combination of BDD based $\mathrm{EO}$ and cathodic $\mathrm{H}_{2} \mathrm{O}_{2}$ production produced $50 \%$ less $\left[\mathrm{ClO}_{4}^{-}\right]$than $\mathrm{EO}$ alone. However, when $\mathrm{O}_{3}$ was introduced, effluent $\left[\mathrm{ClO}_{4}^{-}\right]$raised up due to the depletion of $\mathrm{H}_{2} \mathrm{O}_{2}$ (Lin et al., 2016). A recent study of (Yao et al., 2019) shows that $\mathrm{H}_{2} \mathrm{O}_{2}$ could suppress the formation of TCM and HAAs during the electroperoxone treatment of chloride-containing water. These results imply that $\mathrm{H}_{2} \mathrm{O}_{2}$ can inhibit the reactions between chlorine and organic precursors in the bulk solution.

It is important to note that the quenching effect of $\mathrm{H}_{2} \mathrm{O}_{2}$ may be valid within a current density window. Studies showed that $\mathrm{H}_{2} \mathrm{O}_{2}$ could suppress $\mathrm{ClO}_{4}{ }^{-}$formation when the BDD anode was operated at current densities equal or below $10 \mathrm{~mA} / \mathrm{cm}^{2}$ (Lin et al., 2016; Yang et al., 2019a). However, $\mathrm{ClO}_{4}^{-}$cannot be suppressed by $\mathrm{H}_{2} \mathrm{O}_{2}$ when current densities are above $16 \mathrm{~mA} / \mathrm{cm}^{2}$ (Lin et al., 2016). It seems that $10 \mathrm{~mA} / \mathrm{cm}^{2}$ is a critical point beyond which the benefit of $\mathrm{H}_{2} \mathrm{O}_{2}$ addition could be attenuated.

The addition of $\mathrm{H}_{2} \mathrm{O}_{2}$ could incur different impacts on the EO treatment efficiency, depending on the properties of target pollutants. As shown in Fig. 4, the degradation of PFOS is primarily contributed by DET oxidation. It is found that $\mathrm{H}_{2} \mathrm{O}_{2}$ barely affects PFOS removal due to its weak affinity to the BDD surface. However, the inhibitory effect of $\mathrm{H}_{2} \mathrm{O}_{2}$ is observed in the EO treatment of benzoic acid- a probe readily reacts with $\cdot \mathrm{OH}$. These results imply that if the target compounds are primarily removed via radical-mediated oxidation, then the addition of $\mathrm{H}_{2} \mathrm{O}_{2}$ could be detrimental due to the radical quenching effect (rxn. 11 and 12) (Buxton et al., 1988; Yu, 2004).

$$
\begin{gathered}
\cdot \mathrm{OH}+\mathrm{H}_{2} \mathrm{O}_{2} \rightarrow \mathrm{HO}_{2} \cdot+\mathrm{H}_{2} \mathrm{O} \\
k=2.7 \times 10^{7} \mathrm{M}^{-1} \mathrm{~s}^{-1}
\end{gathered}
$$

$$
\begin{gathered}
\mathrm{Cl} \cdot+\mathrm{H}_{2} \mathrm{O}_{2} \rightarrow \mathrm{HO}_{2} \cdot+\mathrm{H}^{+}+\mathrm{Cl}^{-} \\
k=2 \times 10^{9} \mathrm{M}^{-1} \mathrm{~s}^{-1}
\end{gathered}
$$

Ammonium is another common chlorine scavenger. It reacts with free chlorine to form chloramines. In the chlorination disinfection process, ammonium/ammonia is intentionally introduced to produce chloramine as a disinfectant with less formation potentials of THMs and HAAs (Qi et al., 2004; Hong et al., 2013). The same strategy can be adopted in EO treatment. In the EO treatment of wastewater containing $\mathrm{NH}_{4}^{+}$and $\mathrm{Cl}^{-}$(e.g., latrine wastewater), chloramines are the dominant reactive chlorine species before breakpoint chlorination (Yang et al., 2016; Jasper et al., 2017). Negligible $\mathrm{ClO}_{4}^{-}$, THM, and HAA formation was observed when chloramines prevailed (Jasper et al., 2017; Zhang et al., 2018). The high concentration of $\mathrm{NH}_{4}{ }^{+}$(ca. $30 \mathrm{mmol} / \mathrm{L}$ ) in the latrine wastewater enables the efficient quenching of free chlorine. For the EO treatment of wastewater with less abundant $\mathrm{NH}_{4}^{+}$, whether $\mathrm{NH}_{4}^{+}$should be added intentionally should be evaluated on a case-by-case basis.

\subsection{Optimize operational parameters}

Acidic $\mathrm{pH}$ disfavors the formation of THMs and HAAs in EO treatment (Bagastyo et al., 2012; Yang et al., 2019b), likely through the inhibition of hydrolytic conversion of precursors to THMs and HAAs (Fig. 3) (Chen, 2011). The acidification of water can be readily realized without acid addition in a membrane electrolysis cell (Yang et al., $2019 \mathrm{~b}$ ). In this cell configuration, the anode is separated from cathode by an ion-exchange membrane. Wastewater in the anodic chamber will be rapidly acidified to $\mathrm{pH}<2$, 
while electrolyte in the cathodic chamber will be alkalized to $\mathrm{pH}>13$. Membrane assisted electrolysis was found to accelerate COD and ammonium removal and produce less THMs and HAAs than membrane-free electrolysis (Yang et al., 2019b). The acidic effluent can be neutralized by passing through the cathodic chamber for safe discharge.

Attention should be paid to the control of reaction endpoints. That means overtreatment should be avoided. Take latrine wastewater treatment for example. The complete removal of $\mathrm{COD}$ and $\mathrm{NH}_{4}{ }^{+}$requires an electrolysis duration of 2-4 h (Yang et al., 2016; Yang and Hoffmann, 2016). Under the same condition, the pathogen disinfection ( $5 \mathrm{log}$ removal of E. coli) and the removal of trace pharmaceuticals can be readily achieved within $1 \mathrm{~h}$ (Huang et al., 2016; Jasper et al., 2016). If disinfection is the primary design goal, then the EO treatment should be terminated at $1 \mathrm{~h}$ to avoid reaching break-point chlorination. Jasper et al. (2017) found that when breakpoint chlorination occurs, the concentrations of free chlorine rapidly increased, and such transition is reflected as the sharp increase of oxidation-reduction potential (ORP). From an engineering point of view, optimum reaction endpoints can be controlled by sensors (ORP probe, $\mathrm{NH}_{4}{ }^{+}$selective electrode, free chlorine online detector, etc.).

\subsection{Process integration}

Perchlorate is resistant to homogenous reduction reactions. At neutral $\mathrm{pH}$, it even barely reacts with the hydrated electron, the strongest reductant known (Vellanki et al., 2013). Fortunately, perchlorate can be reduced by biological reactions. Microorganisms collected from saturated aquifer could gain the ability of $\mathrm{ClO}_{4}{ }^{-}$reduction after 20 days of inoculation using emulsify oil as an electron donor (Schaefer et al., 2007). Schaefer et al. (2017) used sand columns bioaugmented with perchloratedegrading bacterium Azospira suillum to treat the effluent of the EO process. It was found that after 150 days of inoculation, sand columns achieved three order-of-magnitude removal of $\mathrm{ClO}_{4}{ }^{-}$at a 9-day residence time. Although Biological processes have low capital and operational costs, the long residence time limits its treatment capacity. Recently, a series of bio-inspired Rhenium (Re) complex catalysts with high $\mathrm{ClO}_{4}^{-}$reduction efficiency were developed. (Liu et al., 2015, 2016) The structures of Re complex catalysts are designed to mimic the structure of molybdopterin in bacterial reductase. Using $\mathrm{H}_{2}$ gas as an electron donor, a complete reduction of perchlorate can be achieved within $2 \mathrm{~h}$. These breakthroughs enable the catalytic hydrogenation techniques to serve as posttreatment processes after EO treatment.

Electrodialysis was used to removed chloride from wastewater and consequently reduced byproduct formation in the downstream EO treatment (Bagastyo et al., 2013).
However, electrodialysis reduces the overall conductivity of water, leading to higher energy consumption of EO treatment. Instead of removing chloride, transferring target compounds from wastewater to electrolytes with controlled composition might be more practical. For instance, PFAS in water can be adsorbed by anion exchange resins. It is a typical operation to regenerate the spent resins by $\mathrm{NaCl}$ solutions (Yu et al., 2009; Deng et al., 2010). The eluent is composed of high concentration $\mathrm{Cl}^{-}$and PFAS. One can envision that the EO treatment of PFAS in the resin regenerant could produce considerable amounts of byproducts. Alternatively, if resins are regenerated by $\mathrm{Na}_{2} \mathrm{SO}_{4}$ solution, then the byproduct formation can be minimized. (Liang et al., 2018)

\subsection{Feasibility analysis}

The section aims to address the advantages and limitations of the above control strategies in views of cost-effectiveness and system complexity. From high to low, the feasibility of strategies (by section number) is ranked in the order of $3.3>3.4>3.2>3.5>3.1$. The addition of quenchers (3.3) and the control of reaction endpoints (3.4) do not require the modification of EO units. Byproduct suppression can be obtained instantly. The addition of $\mathrm{H}_{2} \mathrm{O}_{2}$ will not affect the performance of DET oxidation of some compounds. Thus, the energy consumption of such EO system will not be increased. However, it will be increased for the removal of compounds relying on radical-mediated oxidation, as extended treatment duration will be required to offset the radical-scavenging effect of $\mathrm{H}_{2} \mathrm{O}_{2}$. Attention should also be paid to the elimination of residual $\mathrm{H}_{2} \mathrm{O}_{2}$ before distribution (Barazesh et al., 2015). Anodic oxidation reactions can readily convert $\mathrm{H}_{2} \mathrm{O}_{2}$ to oxygen $\left(E^{0}=-0.682 \mathrm{~V}_{\mathrm{NHE}}\right)$. Additional $\mathrm{EO}$ post-treatment can be deployed, in which active electrodes should be used and operated at a low anodic potential (e.g., $E<E_{\mathrm{Cl}_{2} / \mathrm{Cl}^{-}}^{0}$ : $\left.1.36 \mathrm{~V}_{\mathrm{NHE}}\right)$ to avoid the re-formation of chlorine and byproducts. Significant system modification is required to implement the strategy of cathodic dehalogenation (3.2) and process integration (3.5). Cathodic dehalogenation requires the change of HER active cathode to dehalogenation catalysts. This modification will not affect energy consumption as the water treatment efficiency is still determined by the anodic reactions. Though both treatment efficiency and effluent concentration can be well controlled by process integration, this strategy definitely increases the complexity of the treatment train, which will increase capital and operational costs. More studies are required to investigate the optimum technology combination and the seamless connection between units. The modification of anode material is identified as a strategy with low feasibility. Because DBPs are primarily derived from redox reactions in the bulk solution. The surface coatings for the suppression of DET are not stable. 


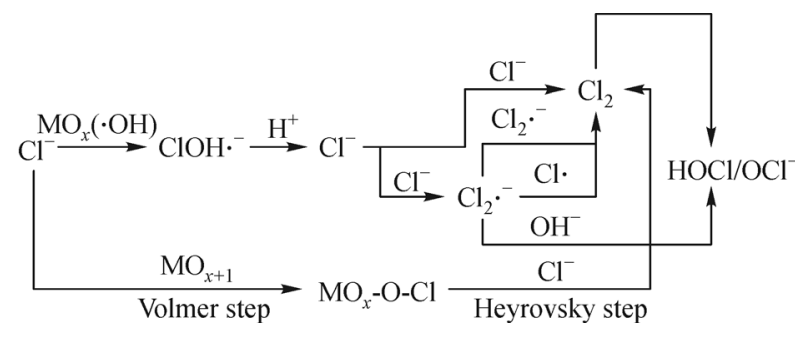

Fig. 5 Transformation of $\mathrm{Cl}^{-}$to chlorine radicals and free chlorine during EO treatment. The figure was modified from ref (Yang et al. 2016).

\section{Future outlook}

Previously, a considerable amount of studies focusing on electrode material development preferred to evaluate the electrode performance in inert electrolytes $\left(\mathrm{Na}_{2} \mathrm{SO}_{4}\right.$, $\mathrm{NaClO}_{4}, \mathrm{Na}_{2} \mathrm{HPO}_{4}$, etc.). In future studies, it is critical to include the tests performed in chloride-bearing solutions, which is more environmentally relevant. In this case, the radical chemistry needs to be revisited. According to the reaction chains in Fig. 5, Electrodes that demonstrated high activity for $\cdot \mathrm{OH}$ production in inert electrolytes might end up producing $\mathrm{Cl}_{2} \cdot{ }^{-}$and $\mathrm{Cl}^{-{ }^{-}}$in real wastewater and surface water containing chloride (Park et al., 2009; Yang et al., 2016). Because $\mathrm{Cl}_{2} \cdot{ }^{-}$and $\mathrm{Cl} \cdot{ }^{-}$have lower redox potentials than $\cdot \mathrm{OH}$, the EO treatment efficiencies of compounds only react with $\cdot \mathrm{OH}$ (e.g., nitrobenzene) could be compromised. One must also note that chloride will be converted to free chlorine at concentrations serval orders of magnitude higher than all of the radicals. (Yang et al., 2016) Though it is even less oxidative than chlorine radicals, free chlorine can significantly enhance the removal of some organics (e.g., phenol, salicylic acid) that are vulnerable to chlorination (Park et al., 2009; Cho et al., 2014).

We have demonstrated that $\mathrm{H}_{2} \mathrm{O}_{2}$ at a concentration higher than $50 \mathrm{mmol} / \mathrm{L}$ can effectively control byproduct formation during the EO treatment of PFAS contaminated groundwater (Yang et al., 2019a). However, the addition of $\mathrm{H}_{2} \mathrm{O}_{2}$ obviously deviate from the original design principle of EO as "chemical-free" processes. The addition of 50 $\mathrm{mmol} / \mathrm{L} \mathrm{H}_{2} \mathrm{O}_{2}$ could incur $\$ 0.6^{-1.2} \mathrm{~m}^{-3}$ extra costs to the EO treatment (Yang et al., 2019a). Thus, the in situ generation of $\mathrm{H}_{2} \mathrm{O}_{2}$ is desired. With this in mind, improvement of EO can be made by combining anodes with carbonaceous cathodes to in situ generate $\mathrm{H}_{2} \mathrm{O}_{2}$. Using pure oxygen, up to 20 wt. $\% \mathrm{H}_{2} \mathrm{O}_{2}$ can be generated electrochemically (Xia et al., 2019). The electro-Fenton or electro-peroxone reactions introduced above all used pure $\mathrm{O}_{2}$ to maintain high $\mathrm{H}_{2} \mathrm{O}_{2}$ concentration in the reactors. Strictly speaking, these techniques are still not chemicalfree processes as auxiliary oxygen tanks need to be deployed. Alternatively, air could be used as an oxygen source by gas diffusion electrode (GDE) (Barazesh et al.,
2015). The GDE cell configuration enables the energyefficient production of $\mathrm{H}_{2} \mathrm{O}_{2}$ at low costs because pressurized gas sources (pump, cylinder, etc.) are no longer required. Recent progress demonstrated that the airGDE pair could produce $\mathrm{H}_{2} \mathrm{O}_{2}$ ranges from 2 to $300 \mathrm{mmol} / \mathrm{L}$ (0.0068 wt.\%-1 wt.\%) (Luo et al., 2015; Barazesh et al., 2015, 2018), which are sufficiently higher than the effective $50 \mathrm{mmol} / \mathrm{L}$ concentration to inhibit perchlorate and DBP formation. Therefore, coupling airGDE with novel anode materials is an exciting direction to advance EO technology.

In this article, we place the spotlight on THMs and HAAs, which are only the tip of the DBP iceberg. We introduced that $\mathrm{NH}_{4}^{+}$could suppress the formation of THMs and HAAs by converting free chlorine to chloramine. However, chloramine might react with matrix organics to form $\mathrm{N}$-nitrosodimethylamine (NDMA), a carcinogenic chemical (McCurry et al., 2017; Selbes et al., 2018). Only a handful of studies reported the electrochemical treatment of NDMA (Chaplin et al., 2009; Almassi et al., 2019). So far, no study reported the formation of NDMA in the electrochemical treatment of wastewater containing both $\mathrm{NH}_{4}{ }^{+}$and $\mathrm{Cl}^{-}$. The report on the formation and transformation of other nitrogen-based and iodinated DBPs is scarce as well. More importantly, the removal of detectable byproducts does not indicate all toxic substances are removed. Given above, the author believes that challenges and opportunities down the road include: 1) develop advanced electrocatalysts and identify best practice to balance treatment efficiency and byproduct formation; 2) close the mass balance of total organic halogen formed in EO treatment by advanced massspectrometric techniques; 3 ) evaluate the toxicity of the EO treated effluents.

Acknowledgements This work is supported by the Bill and Melinda Gates Foundation (BMGF INV-003227).

Open Access This article is licensed under a Creative Commons Attribution 4.0 International License, which permits use, sharing, adaptation, distribution and reproduction in any medium or format, as long as you give appropriate credit to the original author(s) and the source, provide a link to the Creative Commons licence, and indicate if changes were made. The images or other third party material in this article are included in the article's Creative Commons licence, unless indicated otherwise in a credit line to the material. If material is not included in the article's Creative Commons licence and your intended use is not permitted by statutory regulation or exceeds the permitted use, you will need to obtain permission directly from the copyright holder. To view a copy of this licence, visit http://creativecommons.org/licenses/by/4.0/.

\section{References}

Almassi S, Li Z, Xu W, Pu C, Zeng T, Chaplin B P (2019). Simultaneous adsorption and electrochemical reduction of $N$-nitrosodimethylamine using carbon- $\mathrm{Ti}_{4} \mathrm{O}_{7}$ composite reactive electrochemical membranes. Environmental Science \& Technology, 53(2): 928-937

Almassi S, Samonte P R V, Li Z, Xu W, Chaplin B P (2020). 
Mechanistic investigation of haloacetic acid reduction using carbon$\mathrm{Ti}_{4} \mathrm{O}_{7}$ composite reactive electrochemical membranes. Environmental Science \& Technology, 54(3): 1982-1991

Anglada A, Ibanez R, Urtiaga A, Ortiz I (2010). Electrochemical oxidation of saline industrial wastewaters using boron-doped diamond anodes. Catalysis Today, 151(1-2): 178-184

Anglada A, Urtiaga A, Ortiz I (2009). Pilot scale performance of the electro-oxidation of landfill leachate at boron-doped diamond anodes. Environmental Science \& Technology, 43(6): 2035-2040

Bagastyo A Y, Batstone D J, Kristiana I, Gernjak W, Joll C, Radjenovic J (2012). Electrochemical oxidation of reverse osmosis concentrate on boron-doped diamond anodes at circumneutral and acidic $\mathrm{pH}$. Water Research, 46(18): 6104-6112

Bagastyo A Y, Batstone D J, Rabaey K, Radjenovic J (2013). Electrochemical oxidation of electrodialysed reverse osmosis concentrate on $\mathrm{Ti} / \mathrm{Pt}-\mathrm{IrO}_{2}, \mathrm{Ti} / \mathrm{SnO}_{2}-\mathrm{Sb}$ and boron-doped diamond electrodes. Water Research, 47(1): 242-250

Barazesh J M, Hennebel T, Jasper J T, Sedlak D L (2015). Modular advanced oxidation process enabled by cathodic hydrogen peroxide production. Environmental Science \& Technology, 49(12): 73917399

Barazesh J M, Prasse C, Wenk J, Berg S, Remucal C K, Sedlak D L (2018). Trace element removal in distributed drinking water treatment systems by cathodic $\mathrm{H}_{2} \mathrm{O}_{2}$ production and UV photolysis. Environmental Science \& Technology, 52(1): 195-204

Bejan D, Guinea E, Bunce N J (2012). On the nature of the hydroxyl radicals produced at boron-doped diamond and Ebonex ${ }^{\circledR}$ anodes. Electrochimica Acta, 69: 275-281

Bergmann M, Koparal A, Iourtchouk T (2014). Electrochemical advanced oxidation processes, formation of halogenate and perhalogenate species: A critical review. Critical Reviews in Environmental Science and Technology, 44(4): 348-390

Bond T, Goslan E H, Parsons S A, Jefferson B (2012). A critical review of trihalomethane and haloacetic acid formation from natural organic matter surrogates. Environmental Technology Reviews, 1(1): 93-113

Boyce S D, Hornig J F (1983). Reaction pathways of trihalomethane formation from the halogenation of dihydroxyaromatic model compounds for humic acid. Environmental Science \& Technology, 17(4): 202-211

Brillas E, Sirés I, Oturan M A (2009). Electro-Fenton process and related electrochemical technologies based on Fenton's reaction chemistry. Chemical Reviews, 109(12): 6570-6631

Buxton G V, Greenstock C L, Helman W P, Ross A B (1988). Critical review of rate constants for reactions of hydrated electrons, hydrogen atoms and hydroxyl radicals $\left(\mathrm{OH} / \mathrm{O}^{-}\right.$in aqueous solution. Journal of Physical and Chemical Reference Data, 17(2): 513-886

Carter K E, Farrell J (2008). Oxidative destruction of perfluorooctane sulfonate using boron-doped diamond film electrodes. Environmental Science \& Technology, 42(16): 6111-6115

Chaplin B P (2014). Critical review of electrochemical advanced oxidation processes for water treatment applications. Environmental Science. Processes \& Impacts, 16(6): 1182-1203

Chaplin B P (2019). The prospect of electrochemical technologies advancing worldwide water treatment. Accounts of Chemical Research, 52(3): 596-604

Chaplin B P, Schrader G, Farrell J (2009). Electrochemical oxidation of
$N$-nitrosodimethylamine with boron-doped diamond film electrodes. Environmental Science \& Technology, 43(21): 8302-8307

Chen B (2011). Hydrolytic stabilities of halogenated disinfection byproducts: review and rate constant quantitative structure-property relationship analysis. Environmental Engineering Science, 28(6): 385-394

Cho K, Qu Y, Kwon D, Zhang H, Cid C A, Aryanfar A, Hoffmann M R (2014). Effects of anodic potential and chloride ion on overall reactivity in electrochemical reactors designed for solar-powered wastewater treatment. Environmental Science \& Technology, 48(4): 2377-2384

Connick R E (1947). The interaction of hydrogen peroxide and hypochlorous acid in acidic solutions containing chloride ion. Journal of the American Chemical Society, 69(6): 1509-1514

Consonni V, Trasatti S, Pollak F, O'grady W (1987). Mechanism of chlorine evolution on oxide anodes study of $\mathrm{pH}$ effects. Journal of Electroanalytical Chemistry and Interfacial Electrochemistry, 228(12): 393-406

Cotillas S, Llanos J, Rodrigo M A, Cañizares P (2015). Use of carbon felt cathodes for the electrochemical reclamation of urban treated wastewaters. Applied Catalysis B: Environmental, 162: 252-259

Deng S, Yu Q, Huang J, Yu G (2010). Removal of perfluorooctane sulfonate from wastewater by anion exchange resins: effects of resin properties and solution chemistry. Water Research, 44(18): 51885195

Gayen P, Chaplin B P (2017). Fluorination of boron-doped diamond film electrodes for minimization of perchlorate formation. ACS Applied Materials \& Interfaces, 9(33): 27638-27648

Gordon G, Tachiyashiki S (1991). Kinetics and mechanism of formation of chlorate ion from the hypochlorous acid/chlorite ion reaction at $\mathrm{pH}$ 6-10. Environmental Science \& Technology, 25(3): 468-474

Hong H, Xiong Y, Ruan M, Liao F, Lin H, Liang Y (2013). Factors affecting THMs, HAAs and HNMs formation of Jin Lan Reservoir water exposed to chlorine and monochloramine. Science of the Total Environment, 444: 196-204

Horányi G, Bakos I (1992). Experimental evidence demonstrating the occurrence of reduction processes of $\mathrm{ClO}_{4}{ }^{-}$ions in an acid medium at platinized platinum electrodes. Journal of Electroanalytical Chemistry, 331(1-2): 727-737

Huang X, Qu Y, Cid C A, Finke C, Hoffmann M R, Lim K, Jiang S C (2016). Electrochemical disinfection of toilet wastewater using wastewater electrolysis cell. Water Research, 92: 164-172

Hubler D K, Baygents J C, Chaplin B P, Farrell J (2014). Understanding chlorite, chlorate and perchlorate formation when generating hypochlorite using boron doped diamond film electrodes. ECS Transactions, 58(35): 21-32

Jasper J T, Shafaat O S, Hoffmann M R (2016). Electrochemical transformation of trace organic contaminants in latrine wastewater. Environmental Science \& Technology, 50(18): 10198-10208

Jasper J T, Yang Y, Hoffmann M R (2017). Toxic byproduct formation during electrochemical treatment of latrine wastewater. Environmental Science \& Technology, 51(12): 7111-7119

Jawando W, Gayen P, Chaplin B P (2015). The effects of surface oxidation and fluorination of boron-doped diamond anodes on perchlorate formation and organic compound oxidation. Electrochimica Acta, 174: 1067-1078 
Jung Y J, Baek K W, Oh B S, Kang J W (2010). An investigation of the formation of chlorate and perchlorate during electrolysis using $\mathrm{Pt} / \mathrm{Ti}$ electrodes: The effects of $\mathrm{pH}$ and reactive oxygen species and the results of kinetic studies. Water Research, 44(18): 5345-5355

Kesselman J M, Weres O, Lewis N S, Hoffmann M R (1997). Electrochemical production of hydroxyl radical at polycrystalline $\mathrm{Nb}$-doped $\mathrm{TiO}_{2}$ electrodes and estimation of the partitioning between hydroxyl radical and direct hole oxidation pathways. Journal of Physical Chemistry B, 101(14): 2637-2643

Krishtalik L (1981). Kinetics and mechanism of anodic chlorine and oxygen evolution reactions on transition metal oxide electrodes. Electrochimica Acta, 26(3): 329-337

Le T X H, Haflich H, Shah A D, Chaplin B P (2019). Energy-efficient electrochemical oxidation of perfluoroalkyl substances using a $\mathrm{Ti}_{4} \mathrm{O}_{7}$ reactive electrochemical membrane anode. Environmental Science \& Technology Letters, 6(8): 504-510

Li T, Farrell J (2000). Reductive dechlorination of trichloroethene and carbon tetrachloride using iron and palladized-iron cathodes. Environmental Science \& Technology, 34(1): 173-179

Li X F, Mitch W A (2018). Drinking water disinfection byproducts (DBPs) and human health effects: multidisciplinary challenges and opportunities. Environmental Science \& Technology, 52(4): 16811689

Liang S, Pierce R D Jr, Lin H, Chiang S Y, Huang Q J (2018). Electrochemical oxidation of PFOA and PFOS in concentrated waste streams. Remediation Journal, 28(2): 127-134

Lin Z, Yao W, Wang Y, Yu G, Deng S, Huang J, Wang B (2016). Perchlorate formation during the electro-peroxone treatment of chloride-containing water: effects of operational parameters and control strategies. Water Research, 88: 691-702

Liu J, Choe J K, Wang Y, Shapley J R, Werth C J, Strathmann T J (2015). Bioinspired complex-nanoparticle hybrid catalyst system for aqueous perchlorate reduction: Rhenium speciation and its influence on catalyst activity. ACS Catalysis, 5(2): 511-522

Liu J, Han M, Wu D, Chen X, Choe J K, Werth C J, Strathmann T J (2016). New bioinspired perchlorate reduction catalyst with significantly enhanced stability via rational tuning of rhenium coordination chemistry and heterogeneous reaction pathway. Environmental Science \& Technology, 50(11): 5874-5881

Luo H, Li C, Wu C, Dong X (2015). In situ electrosynthesis of hydrogen peroxide with an improved gas diffusion cathode by rolling carbon black and PTFE. RSC Advances, 5(80): 65227-65235

Mahmudov R, Shu Y, Rykov S, Chen J, Huang C P (2008). The reduction of perchlorate by hydrogenation catalysts. Applied Catalysis B: Environmental, 81(1-2): 78-87

Mao R, Lan H, Yan L, Zhao X, Liu H, Qu J (2018). Enhanced indirect atomic $\mathrm{H}^{*}$ reduction at a hybrid $\mathrm{Pd} /$ graphene cathode for electrochemical dechlorination under low negative potentials. Environmental Science. Nano, 5(10): 2282-2292

Mao R, Li N, Lan H, Zhao X, Liu H, Qu J, Sun M (2016). Dechlorination of trichloroacetic acid using a noble metal-free graphene- $\mathrm{Cu}$ foam electrode via direct cathodic reduction and atomic $\mathrm{H}^{*}$. Environmental Science \& Technology, 50(7): 3829-3837

Martínez - Huitle C A, Brillas E, (2008). Electrochemical alternatives for drinking water disinfection. Angewandte Chemie International Edition, 47(11): 1998-2005
Martínez-Huitle C A, Rodrigo M A, Sirés I, Scialdone O (2015). Single and coupled electrochemical processes and reactors for the abatement of organic water pollutants: A critical review. Chemical Reviews, 115 (24): 13362-13407

McCurry D L, Ishida K P, Oelker G L, Mitch W A (2017). Reverse osmosis shifts chloramine speciation causing Re-formation of NDMA during potable reuse of wastewater. Environmental Science \& Technology, 51(15): 8589-8596

Mostafa E, Reinsberg P, Garcia-Segura S, Baltruschat H (2018). Chlorine species evolution during electrochlorination on borondoped diamond anodes: In-situ electrogeneration of $\mathrm{Cl}_{2}, \mathrm{Cl}_{2} \mathrm{O}$ and $\mathrm{ClO}_{2}$. Electrochimica Acta, 281: 831-840

Navalon S, Alvaro M, Garcia H (2008). Carbohydrates as trihalomethanes precursors. Influence of $\mathrm{pH}$ and the presence of $\mathrm{Cl}^{-}$and $\mathrm{Br}$ on trihalomethane formation potential. Water Research, 42(14): 3990-4000

Niu J, Lin H, Gong C, Sun X (2013). Theoretical and experimental insights into the electrochemical mineralization mechanism of perfluorooctanoic acid. Environmental Science \& Technology, 47 (24): 14341-14349

Park H, Vecitis C D, Hoffmann M R (2009). Electrochemical water splitting coupled with organic compound oxidation: The role of active chlorine species. Journal of Physical Chemistry C, 113(18): 7935-7945

Pourmoghaddas H, Stevens A A (1995). Relationship between trihalomethanes and haloacetic acids with total organic halogen during chlorination. Water Research, 29(9): 2059-2062

Qi Y, Shang C, Lo I M (2004). Formation of haloacetic acids during monochloramination. Water Research, 38(9): 2375-2383

Radjenović J, Farré M J, Mu Y, Gernjak W, Keller J (2012). Reductive electrochemical remediation of emerging and regulated disinfection byproducts. Water Research, 46(6): 1705-1714

Richardson S D, Plewa M J, Wagner E D, Schoeny R, Demarini D M (2007). Occurrence, genotoxicity, and carcinogenicity of regulated and emerging disinfection by-products in drinking water: A review and roadmap for research. Mutation Research/Reviews in Mutation Research, 636(1-3): 178-242

Rook J J (1977). Chlorination reactions of fulvic acids in natural waters. Environmental Science \& Technology, 11(5): 478-482

Rusanova M Y, Polášková P, Muzikař M, Fawcett W R (2006). Electrochemical reduction of perchlorate ions on platinum-activated nickel. Electrochimica Acta, 51(15): 3097-3101

Schaefer C, Fuller M, Condee C, Lowey J, Hatzinger P (2007). Comparison of biotic and abiotic treatment approaches for comingled perchlorate, nitrate, and nitramine explosives in groundwater. Journal of Contaminant Hydrology, 89(3-4): 231-250

Schaefer C E, Andaya C, Burant A, Condee C W, Urtiaga A, Strathmann T J, Higgins C P (2017). Electrochemical treatment of perfluorooctanoic acid and perfluorooctane sulfonate: Insights into mechanisms and application to groundwater treatment. Chemical Engineering Journal, 317: 424-432

Schaefer C E, Andaya C, Urtiaga A (2015). Assessment of disinfection and by-product formation during electrochemical treatment of surface water using a $\mathrm{Ti} / \mathrm{IrO}_{2}$ anode. Chemical Engineering Journal, 264: 411-416

Selbes M, Beita-Sandí W, Kim D, Karanfil T (2018). The role of 
chloramine species in NDMA formation. Water Research, 140: 100 109

Sérodes J B, Rodriguez M J, Li H, Bouchard C (2003). Occurrence of THMs and HAAs in experimental chlorinated waters of the Quebec City area (Canada). Chemosphere, 51(4): 253-263

Sun Y X, Wu Q Y, Hu H Y, Tian J (2009). Effects of operating conditions on THMs and HAAs formation during wastewater chlorination. Journal of Hazardous Materials, 168(2-3): 1290-1295

Thurman E M (2012). Organic Geochemistry of Natural Waters. Berlin: Springer Science \& Business Media, 90-92

Trasatti S (1984). Electrocatalysis in the anodic evolution of oxygen and chlorine. Electrochimica Acta, 29(11): 1503-1512

Trasatti S (1987). Progress in the understanding of the mechanism of chlorine evolution at oxide electrodes. Electrochimica Acta, 32(3): 369-382

Urbansky E T, Schock M (1999). Issues in managing the risks associated with perchlorate in drinking water. Journal of Environmental Management, 56(2): 79-95

USEPA (2010). Comprehensive Disinfectants and Disinfection Byproducts Rules (Stage 1 and Stage 2): Quick Reference Guide. Available online at the website of www.epa.gov/ground-water-and-drinkingwater (accessed May 03, 2020)

Vellanki B P, Batchelor B, Abdel-Wahab A (2013). Advanced reduction processes: A new class of treatment processes. Environmental Engineering Science, 30(5): 264-271

Wagner E D, Plewa M J (2017). CHO cell cytotoxicity and genotoxicity analyses of disinfection by-products: an updated review. Journal of Environmental Sciences (China), 58: 64-76

Wang D, Huang C, Chen J, Lin H, Shah S (2007). Reduction of perchlorate in dilute aqueous solutions over monometallic nanocatalysts: Exemplified by tin. Separation and Purification Technology, 58(1): 129-137

Wang L, Lu J, Li L, Wang Y, Huang Q (2020). Effects of chloride on electrochemical degradation of perfluorooctanesulfonate by Magnéli phase $\mathrm{Ti}_{4} \mathrm{O}_{7}$ and boron doped diamond anodes. Water Research, 170: 115254

Wasberg M, Horányi G (1995). The reduction of $\mathrm{ClO}_{4}-$ ions on $\mathrm{Rh}$ electrodes. Journal of Electroanalytical Chemistry, 385(1): 63-70

Xia C, Xia Y, Zhu P, Fan L, Wang H (2019). Direct electrosynthesis of pure aqueous $\mathrm{H}_{2} \mathrm{O}_{2}$ solutions up to $20 \%$ by weight using a solid electrolyte. Science, 366(6462): 226-231

Yang S, Fernando S, Holsen T M, Yang Y (2019a). Inhibition of perchlorate formation during the electrochemical oxidation of perfluoroalkyl acid in groundwater. Environmental Science \& Technology Letters, 6(12): 775-780

Yang Y, Hoffmann M R (2016). Synthesis and stabilization of blue-black $\mathrm{TiO}_{2}$ nanotube arrays for electrochemical oxidant generation and wastewater treatment. Environmental Science \& Technology, 50(21): 11888-11894

Yang Y, Kao L C, Liu Y, Sun K, Yu H, Guo J, Liou S Y H, Hoffmann M $\mathrm{R}$ (2018). Cobalt-doped black $\mathrm{TiO}_{2}$ nanotube array as a stable anode for oxygen evolution and electrochemical wastewater treatment. ACS
Catalysis, 8(5): 4278-4287

Yang Y, Lin L, Tse L K, Dong H, Yu S, Hoffmann M R (2019b). Membrane-separated electrochemical latrine wastewater treatment. Environmental Science. Water Research \& Technology, 5(1): 51-59

Yang Y, Shin J, Jasper J T, Hoffmann M R (2016). Multilayer heterojunction anodes for saline wastewater treatment: Design strategies and reactive species generation mechanisms. Environmental Science \& Technology, 50(16): 8780-8787

Yao W, Fu J, Yang H, Yu G, Wang Y (2019). The beneficial effect of cathodic hydrogen peroxide generation on mitigating chlorinated byproduct formation during water treatment by an electro-peroxone process. Water Research, 157: 209-217

Yu Q, Zhang R, Deng S, Huang J, Yu G (2009). Sorption of perfluorooctane sulfonate and perfluorooctanoate on activated carbons and resin: Kinetic and isotherm study. Water Research, 43 (4): $1150-1158$

Yu X Y (2004). Critical evaluation of rate constants and equilibrium constants of hydrogen peroxide photolysis in acidic aqueous solutions containing chloride ions. Journal of Physical and Chemical Reference Data, 33(3): 747-763

Yuan S, Li Z, Wang Y (2013). Effective degradation of methylene blue by a novel electrochemically driven process. Electrochemistry Communications, 29: 48-51

Zaky A M, Chaplin B P (2013). Porous substoichiometric $\mathrm{TiO}_{2}$ anodes as reactive electrochemical membranes for water treatment. Environmental Science \& Technology, 47(12): 6554-6563

Zaky A M, Chaplin B P (2014). Mechanism of $p$-substituted phenol oxidation at a $\mathrm{Ti}_{4} \mathrm{O}_{7}$ reactive electrochemical membrane. Environmental Science \& Technology, 48(10): 5857-5867

Zhang C, He D, Ma J, Waite T D (2018). Active chlorine mediated ammonia oxidation revisited: Reaction mechanism, kinetic modelling and implications. Water Research, 145: 220-230

Zhuo Q, Deng S, Yang B, Huang J, Wang B, Zhang T, Yu G (2012). Degradation of perfluorinated compounds on a boron-doped diamond electrode. Electrochimica Acta, 77: 17-22

Zöllig H, Remmele A, Fritzsche C, Morgenroth E, Udert K M (2015). Formation of chlorination byproducts and their emission pathways in chlorine mediated electro-oxidation of urine on active and nonactive type anodes. Environmental Science \& Technology, 49(18): 1106211069

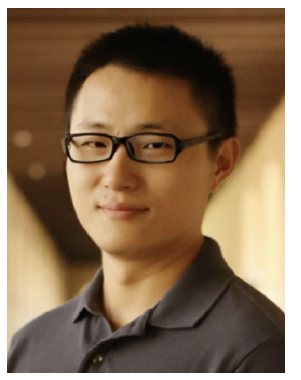

Dr. Yang Yang received his B.S. (2019) and Ph.D. (2014) degrees from South China University of Technology and Tsinghua University, respectively. Before joining Clarkson University in 2019, he was a postdoc and a senior research scientist at Caltech. His research interests have spanned the subject areas of electrochemistry, water chemistry, and heterogeneous catalysis. 